\title{
THE PHYLOGENETIC RELATIONSHIPS AMONG REQUIEM AND HAMMERHEAD SHARKS: INFERRING PHYLOGENY WHEN THOUSANDS OF EQUALLY MOST PARSIMONIOUS TREES RESULT
}

\author{
Gavin J. P. Naylor \\ ${ }^{1}$ Department of Biology University of Michigan, \\ Ann Arbor, Michigan 48109-1048, U.S.A.
}

Received for publication 20 August 1992; accepted 6 October 1992

\begin{abstract}
Protein variation among 37 species of carcharhiniform sharks was examined at 17 presumed loci. Evolutionary trees were inferred from these data using both cladistic character and a distance Wagner analysis. Initial cladistic character analysis resulted in more than 30000 equally parsimonious tree arrangements. Randomization tests designed to evaluate the phylogenetic information content of the data suggest the data are highly significantly different from random in spite of the large number of parsimonious trees produced. Different starting seed trees were found to influence the kind of tree topologies discovered by the heuristic branch swapping algorithm used. The trees generated during the early phases of branch swapping on a single seed tree were found to be topologically similar to those generated throughout the course of branch swapping. Successive weighting increased the frequency and the consistency with which certain clades were found during the course of branch swapping, causing the semi-strict consensus to be more resolved. Successive weighting also appeared resilient to the bias associated with the choice of initial seed tree causing analyses seeded with different trees to converge on identical final character weights and the same semi-strict consensus tree.

The summary cladistic character analysis and the distance Wagner analysis both support the monophyly of two major clades, the genus Rhizoprionodon and the genus Sphyma.. The distance Wagner analysis also supports the monophyly of the genus Carcharhinus. However, the cladistic analysis suggests that Carcharhinus is a paraphyletic group that includes the blue shark Prionace glauca.
\end{abstract}

\section{Introduction}

Carcharhiniform sharks comprise about $55 \%$ of the approximately 350 living shark species. The Carcharhiniformes are currently divided into eight families: The cat sharks (Sciliorhinidae), the finback catsharks (Proscillidae), the false catsharks (Pseudotriakidae), the barbelled houndsharks (Leptocharidae), houndsharks (Triakidae), the weasel and snaggletoothed sharks (Hemigalidae), the requiem sharks (Carcharhinidae) and the hammerhead sharks (Sphyrnidae) (Compagno, 1988). Of these eight families, the requiem sharks and the hammerhead sharks are generally better known due to the large size of several of their constituent species, their occasional implication in shark attacks and their increasing commercial importance to fisheries.

Carcharhinus contains more species than any other genus within the family Carcharhinidae. It comprises 30 species whose collective ranges spread over tropical, sub-tropical and temperate regions (Garrick, 1982; Bigelow and Schroeder, 1948; Compagno, 1984). Many species within the genus are phenotypically similar and are often taxonomically confused. The confusion is frequently compounded by extensive intraspecific variation among geographically isolated populations. As a result, a number of synonyms have been used to describe species 
within the genus. Recent revisions by Garrick (1982, 1985), indicate that only 30 (out of more than 100) of these nominal species are valid.

The marked heterogeneity within species and morphological uniformity among most species of Carcharhinus has allowed intra-generic relationships to be proposed from morphological data for only the most obvious sibling species pairs (Garrick, 1982), i.e. C. sealei-C. dussumeri, C. leucas-C. amboinensis, C. limbatus-C. amblyrhynchoides and C. amblyrhynchos-C. wheleri. The establishment of phylogenetic relationships beyond these pairs had not been rigorously attempted (with the exception of Baranes and Shahrabany-Baranes, 1986, who used phenetic clustering of morphometric data) until Lavery surveyed allozyme variation in 21 carcharhiniform taxa (Lavery, 1992). The present study represents an effort to investigate the phylogenetic relationships within the genus Carcharhinus, and among its closely related taxa using allozyme data derived from 37 Carcharhiniform taxa, 11 of which were included in the survey by Lavery (1992).

\section{Materials and Methods}

Sharks were collected in the field and from fish markets between February 1984 and December 1987 from south Australia, the east and Gulf coasts of North America, Belize, the Bahamas, Trinidad, the gulf of Aqaba in the Red Sea, the Philippines and the northwestern Hawaiian Islands. Samples of specimens were taken by me with the exception of two C. galapagensis which were collected by Mark Suiso of the Sea Grant Program in Oahu Hawaii, and one C. altimus collected by Dr J. Musick of the Virginia Institute of Marine Science. A total of 21 (out of a possible 30) different species of Carcharhinus and 16 species from eight other carcharhiniform genera that are closely related to Carcharhinus, were surveyed. Localities and samples sizes are given in Appendix 1.

Samples of heart, liver, kidney and skeletal muscle were removed from each shark in the field (approximately 2 grams of each), placed in separate cryotubes and kept in liquid nitrogen until transported to the laboratory where they were stored at $-75^{\circ} \mathrm{C}$. Approximately half of each tissue sample was homogenized in an equal volume of distilled water and centrifuged at $0^{\circ} \mathrm{C}$ and $12000 \mathrm{~g}(10000 \mathrm{rpm})$ for 10 minutes. Supernatants were frozen at $-75^{\circ} \mathrm{C}$ until required for clectrophoresis.

Supernatant fractions were run in horizontal starch gels made up with $12.5 \%$ Connaught Starch and 7\% sucrose, by weight. Gels were prepared using one of seven different buffers as outlined by Selander et al. (1971). More than 35 presumed loci were initially screencd, of which 17 showed activity clearly enough to be scored. A list of optimum buffers and tissues used for the 17 presumed loci is presented in Table 1 . The relative mobility of electromorphs was scored either directly from primary gels or from secondary "line up" comparison gels sensu Richardson et al. (1986) when electromorphs were seen to have closely similar mobilities.

\section{Phylogenetic: Anai.ysis}

Data collected in the present study were subjected to both cladistic character and distance Wagner analysis (Farris, 1972) using Cavalli-Sforza and Edwards (1967) 
Table 1

Presumed loci scored, tissues used and electrophoretic conditions

\begin{tabular}{|c|c|c|c|c|c|}
\hline Protein & $\begin{array}{c}\text { Locus } \\
\text { acronym }^{n}\end{array}$ & $\begin{array}{c}\text { Enzyme } \\
\text { commission No. }\end{array}$ & $\begin{array}{l}\text { Tissue } \\
\text { type }\end{array}$ & $\begin{array}{c}\text { Electrophoretic } \\
\text { conditions }^{d i}\end{array}$ & $\begin{array}{l}\text { Stain } \\
\text { reference' }\end{array}$ \\
\hline Aspartate amino transferase & GOT-1 & 2.6 .1 .1 & $\mathbf{H}$ & 1 & 1 \\
\hline Aspartate amino transferase & GOT-2 & $2.6 .1,1$ & $\mathrm{H}$ & 1 & 1 \\
\hline Carbonate dehydratase & CA & 4.2 .1 .1 & $\mathbf{K}$ & 5 & $\tilde{3}$ \\
\hline Dipeptidase $f$ & PFP & 3.4 .13 .11 & $\mathrm{H}$ & 6 & 5 \\
\hline Esterase & EST-1 & 3.1 .1 .1 & $\mathrm{H}$ & 2 & 5 \\
\hline Esterase & EST-02 & 3.1.1.1 & $\mathrm{H}$ & 2 & 5 \\
\hline Isocitrate dehydrogenase & IDH & 1.1 .1 .42 & $\mathrm{H}$ & 5 & j \\
\hline Glutamate dehydrogenase & $\mathrm{GDH}$ & 1.4 .1 .3 & $\mathrm{k}$ & 5 & 3 \\
\hline Glycerol-3-phosphate dehydrogenase & $\alpha G P D$ & 1.1 .1 .8 & $\mathrm{M}$ & 2 & $\ddot{1}$ \\
\hline Leucine amino peptidase & IAP & 3.4 .11 & $\mathrm{H}$ & 3 & 1 \\
\hline lactate dehydrogenase & L.DH & 1.1 .1 .27 & $\mathrm{H}$ & 1 & 5 \\
\hline Lactoyl glutathione lyase & GL,O & 4.4 .15 & $\mathrm{~K}$ & 7 & f \\
\hline Malic enzyme & ME-1 & 1.1 .1 .40 & $\mathbf{M}$ & 9 & $\underline{2}$ \\
\hline Malic enzyme & ME-2 & 1.1 .1 .40 & $\mathbf{M}$ & 2 & 2 \\
\hline Malate dehydrogenase & $\mathrm{MDH}$ & 1.1 .37 & $\mathrm{H}$ & 3 & 1 \\
\hline Superoxide dismutase & SOD-1 & 1.15 .1 .1 & $\mathrm{H}$ & 4 & $\underline{2}$ \\
\hline Superoxide dismutase & SOD-2 & 1.15 .1 .1 & $\mathrm{H}$ & 4 & $\because$ \\
\hline
\end{tabular}

"Locus acronyms follow Richardson et al. (1986).

${ }^{b}$ Nomenclature Committee of the International Union of Biochemistry (1978).

' $\mathrm{H}$, heart muscle; $\mathrm{K}$, kidney; $\mathrm{M}$, skeletal muscle.

${ }^{d}$ l, Tris-citrate EDTA, $250 \mathrm{~V}, 5 \mathrm{~h} ; 2$, Tris-versene-borate, $200 \mathrm{~V} .6 \mathrm{~h} ; 3$, Tris-citrate $\mathrm{pH} 6.7,150 \mathrm{~V}, 5.5 \mathrm{~h}$; 4, Poulik, 250 V, 5-6 h; 5. Tris-citrate $\mathrm{pH} 8.0,130 \mathrm{~V}, 5 \mathrm{~h}: 6$. Lithium hydroxide, $350 \mathrm{~V}, 6 \mathrm{~h}$ h: 7, Tris-HCl, $250 \mathrm{~V}, 5 \mathrm{~h}$.

1, Selander et al. (1971); 2, Siciliano and Shaw (1976); 3, Shaw and Prasad (1970); 4, Harris and Hopkinson (1976); 5, Recipes routinely used in the laborator of R. Highton and outlined in Hedge's (1986).

'Glycyl leucine used as substrate for Dipeptidase.

chord distance. Hemigaleus microstoma and Hemigaleus macrostoma were used as the combined outgroup in both analyses. Hemigaleids are regarded as the sister group to the carcharhinids and sphyrnids based on a number of morphological characters (Compagno, 1988: 255-256).

A cladistic parsimony analysis was carried out using the computer program PAUP, version 3.0k (Swofford, 1990) on a Macintosh Ilci. Each presumptive locus was treated as a character. Electromorphs within loci were treated as unordered character states. In the few cases where heterozygotes were encountered. the most common electromorph was entered as the character state. As apparent heterozygosity over all presumed loci was low (less than 2\%), and most samples were represented by five specimens, this method of coding proved satisfactory for all but two cases. These were both cases where the taxon was represented by a single specimen which was heterozygous for the presumed locus under study. In both cases specimens were heterozygous for one unique electromorph and one shared with other taxa. They were thus scored as possessing the shared electromorph.

A heuristic procedure was used to search for most parsimonius trees. The stepwise addition (simple) option of PAUP was used to generate the initial seed tree (seed "A") while the tree bisection reconnection (TBR) option was used to implement branch swapping. Only tree topologies of minimum length were retained for subsequent branch swapping. Because a large number of taxa were included in the survey and because electrophoretic mobility characters were coded without anv 
presupposed transformation sequence (unordered), a large number (37267) of most parsimonious trees (MPTs) were generated.

\section{Evaluation of Multiple Most Parsimonious Trees}

\section{The phylogenetic information content of the data}

The phylogenetic information content of the data set was evaluated using the randomization tests of Archie (1989). Character state assignments were randomly permuted within each character of the original data matrix to remove phylogenetic information (Archie, 1989). Fifty different randomized matrices were generated, each one reflecting the character state distribution of the original data. Each matrix was subsequently subjected to the heuristic (TBR) tree searching procedure of PAUP 3.0k. Searches were left to run to exhaustion or were stopped once 10000 MPTs had been found. The tree length derived from the original data matrix was contrasted with the histogram of tree lengths derived from the 50 randomized matrices (Fig. 2) and subjected to a one-sample $t$-test.

\section{Seed tree bias}

The effect of different starting seed trees on the outcome was investigated by contrasting results using stepwise addition (seed "A", set "A") with those obtained from a second seed tree, " $B$ " constructed using random addition (set " $B$ "). This second tree "B" was subjected to TBR branch swapping until 20000 MPTs had been generated. A majority rule consensus of the 20000 seed " $B$ " trees was constructed and contrasted with the majority rule consensus of the seed " $A$ " trees.

\section{Signal consistency during branch swapping}

Sub-samples of trees produced by branch swapping were taken to test whether the same "kinds" of trees were produced throughout the course of a heuristic search. Each sub-sample comprised a block of 5000 trees produced sequentially by the branch swapping algorithm (i.e. tree Nos 1-5000, 5001-10000, 10001$15000,15001-20000$ ). Majority rule consensus trees were constructed for each block of 5000 trees and compared with one another and with the majority rule consensus tree for all 20000 trees using partition distances (Penny and Hendy, 1985). This procedure was carried out separately for trees in set A and for trees in set $\mathrm{B}$.

The consistency of the hierarchical signal among sub-samples was also investigated graphically sensu Naylor (1992). Each sub-sample of 5000 trees was subjected to the plot group frequency option of PAUP. This option orders "groups found" (clades) by their frequency of occurrence in a sample of MPTs. The "groups found" in sub-samples were re-ordered to coincide with the order found for the entire 20000 tree set. The frequency of occurrence of "groups found" was plotted for each of the four sub-samples and compared. This procedure was carried out separately for both tree sets $\mathrm{A}$ and $\mathrm{B}$.

\section{Successive weighting}

Successive weighting (Farris, 1969, 1989; Carpenter, 1988) was adopted in an attempt to reduce the number of most parsimonious trees produced. Autapomorphic character states (electromorphs) were removed from the data set and 
recoded as missing values to ensure that the rescaled consistency indices used in successive weighting were not artificially inflated (see Farris, 1989). Characters (presumed loci) were weighted according to the best fits of their rescaled consistency indices to the initial 20000 trees. TBR branch swapping was carried out on the initial seed tree with the new character weights enforced. After 20000 new trees had been generated, the characters were re-weighted according to their new best fits. This protocol was re-iterated until character weights stabilized, at which point the semi-strict consensus of the resultant set of trces was computed. The procedure was applied to tree sets A and B, separately.

The two final sets of successively weighted trees (one from set $A$, the other from set B) were sub-sampled as outlined above. Hierarchical signal constancy among sub-samples within tree sets, and between tree sets, was contrasted with its counterpart in the unweighted analysis.

The topology of the distance Wagner tree was entered into PAUP to determine its length.

\section{Results and Discussion}

A total of 201 electromorphs was detected over the 17 presumed loci surveyed. Of these 116 (58\%) were found to be unique (autapomorphic) to individual taxa. The electromorphs detected were alphabetically coded in the character state matrix to reflect their relative electrophoretic mobilities and are presented in Appendix 2a. Those most anodal are denoted by " $A$ " while the most cathodal are denoted by " $Z$ ". (Because 27 alleles were found at the PEP locus the most cathodal allele was scored using the integer symbol " 1 ".)

The rooted distance Wagner network (Fig. 1) had a cophenetic correlation coefficient of 0.929 , an $F$ value of 7.1 (Prager and Wilson, 1976) and a length of 92 steps when fitted to the character matrix.

32767 most parsimonious trees (MPTs) of length 86 steps (computed excluding autapomorphies) and retention index (RI) 0.892 (Farris, 1989) were generated by branch swapping (TBR) on seed tree "A". This number represents a ceiling imposed by computer memory rather than a complete set of MPTs. 20000 MPTs of length 86 steps and RI 0.892 were generated by branch swapping on the seed tree " $B$ " at which point TBR branch swapping was deliberately interrupted. Results of the randomization tests indicate that the MPT length of 86 steps is 31.44 standard deviations shorter than the mean MPT length of 159.18 found for the 50 randomized data sets (Fig. 2), suggesting that the data matrix has a high overall phylogenetic content even though it yields a large number of MPTs.

The majority rule consensus tree (Margush and McMorris, 1981) for set A was resolved into 27 component forks [Fig. 3(a)]. The majority rule consensus tree for set $B$ was resolved into (29) component forks [Fig. 4(a)] which differed in topological structure from that of set A.

\section{SuB-SAMPL ES}

In the unweighted implementation, majority rule trees for sub-samples within a tree set yielded closely similar topologies to the majority rule tree for all trees in a set. This similarity in "hierarchical signal" throughout the course of branch 

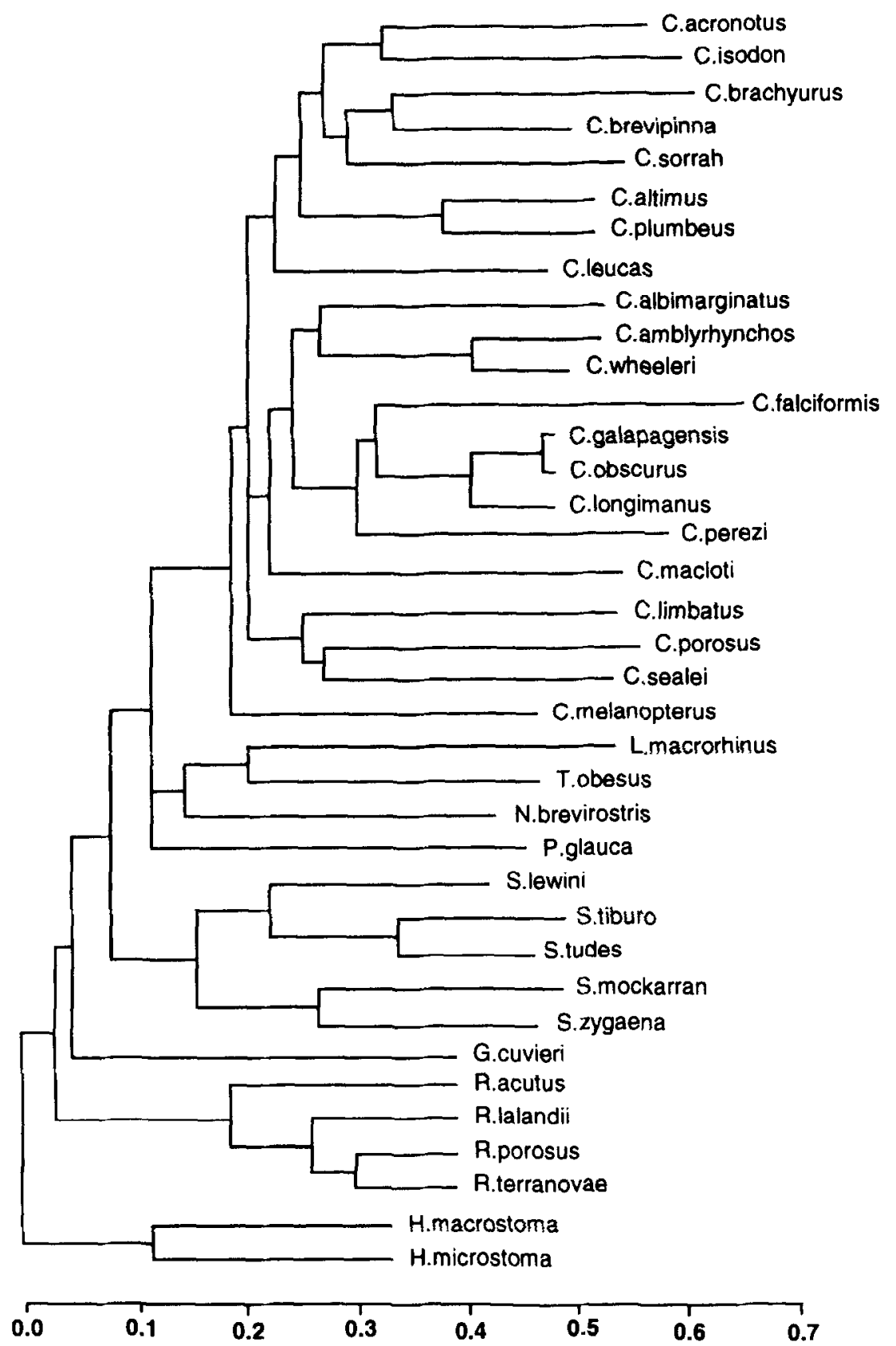

DISTANCE FROM ROOT

Fig. 1. Distance Wagner tree (Farris, 1972) of 37 species of carcharhiniform sharks. The tree was constructed using Cavalli-Sforza and Edwards (1967) chord distance and was rooted with the two species of Hemigaleus as an outgroup. The tree topology had a length of 92 steps when fitted to the original character state matrix. 


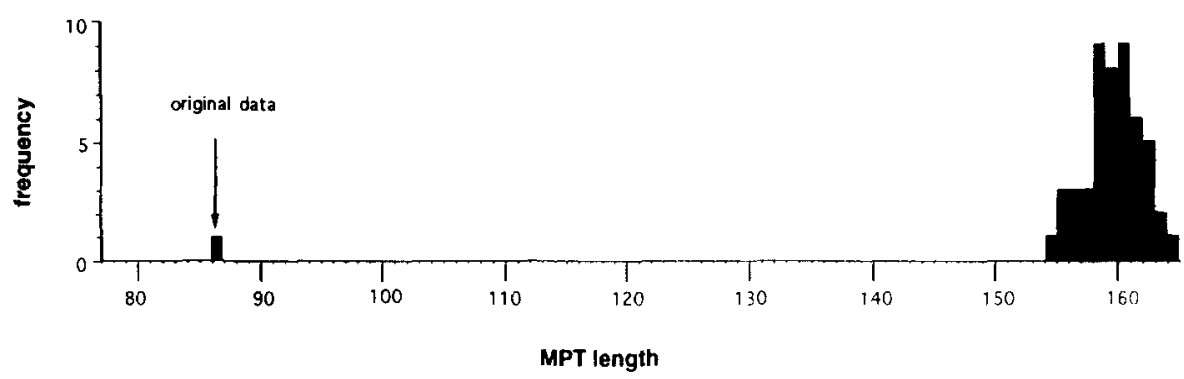

Fig. 2. Histogram plot of most parsimonious tree lengths derived from 50 random permutations of the data matrix (Archie, 1989). The original data matrix yields an MPT length of 86 steps which is 31.44 standard deviations shorter than the mean of 159.18 steps found for the permuted data sets, suggesting that the original data matrix has latent hierarchical structure.

swapping on a single starting tree is also reflected in the sub-sample group frequency plots (Fig. 5). The minor variation among sub-samples within tree sets contrasts with the variation between tree sets $A$ and $B$ in the pair-wise matrix of trec partition distance [Fig. 6(a)]. The partition indices clearly show within tree set distances to be about five times smaller than among tree set distances. This probablv corresponds to different "islands of trees" as put forward by Maddison (1991).

The topological similarity in majority rule trees among sub-samples within it tree set, suggests that only a portion of the total number of trees resulting from a heuristic search are required to estimate the majority rule consensus over all the trees in a tree set. It follows from this that, if one is obliged to use heuristic searching methods and has to choose between the alternatives of executing incomplete searches on different seed trees or executing one search to conclusion on a single seed tree, one is better advised to use the several seeds option.

The topological similarity in majority rule trees among sub-samples within a tree set also shows that majority rule consensus more accurately reflects the constancs of the hierarchical signal produced throughout the course of branch swapping on a single seed tree than does the semi-strict consensus. (The semi-strict consensus becomes less resolved as more "rare" groups are found during the course of branch swapping; by contrast, the majority rule consensus, being unaffected $b$ rare topologies, reflects the predominant hierarchical signal throughout branch swapping).

\section{SUICGESSIVE WEIGHTING}

Successive weighting resulted in the stabilization of weights after three iterations. The final weights for tree set A were identical to those of tree set $B$ (final weights are presented in Appendix 2b). The semi-strict consensus tree had the same topology for both tree sets, suggesting that the successive weighting procedure is less sensitive to bias arising from different seed trees. (Further work on other data sets will be required to test the generality of this supposition).

Sub-sampling of the final set of successively weighted trees from both tree sets revealed a different hierarchical signal profile during branch swapping than was observed for the unweighted implementation as described by Naylor (1992). Frequency distributions of groups found (Fig. 5) had broad plateau regions at the top of curves corresponding to higher numbers of groups found in $100 \%$ of trees 
within sub-samples, and shorter tails corresponding to fewer groups found in less than $5 \%$ of trees within each sub-sample. Little variation was seen across subsamples for groups found at high frequencies (above 95\%). However, variation comparable to that seen for the trees derived from the unweighted data was seen for groups found at frequencies less than $95 \%$.

Interestingly, within-tree set distances are smaller than among-tree set distances

(a) Majority rule consensus - No weighting

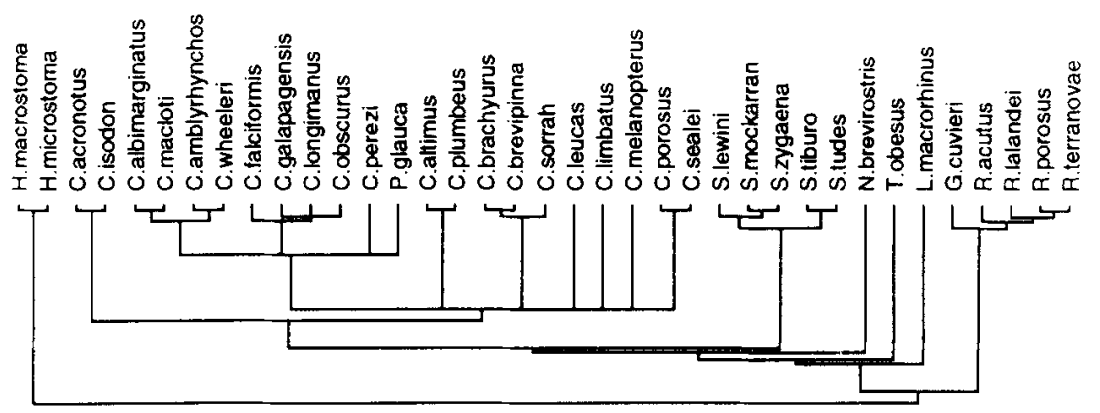

(b) Semi-strict consensus - No weighting

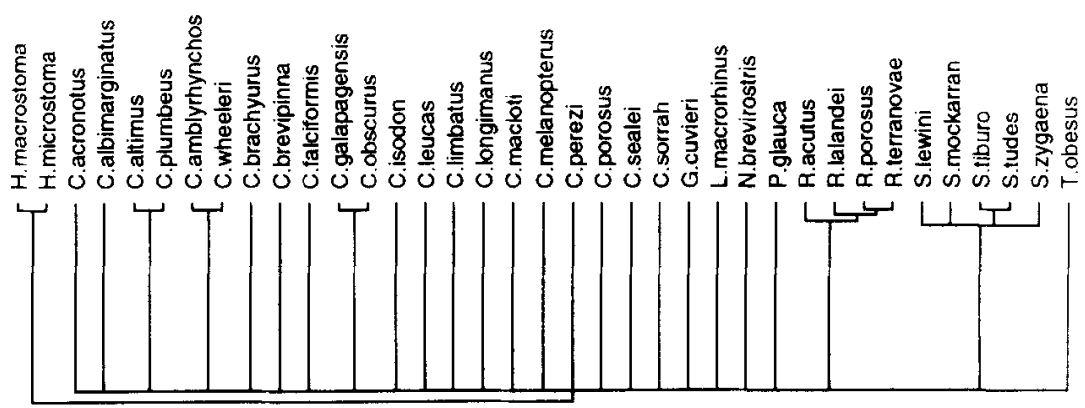

(c) Semi-strict consensus - Successive weighting

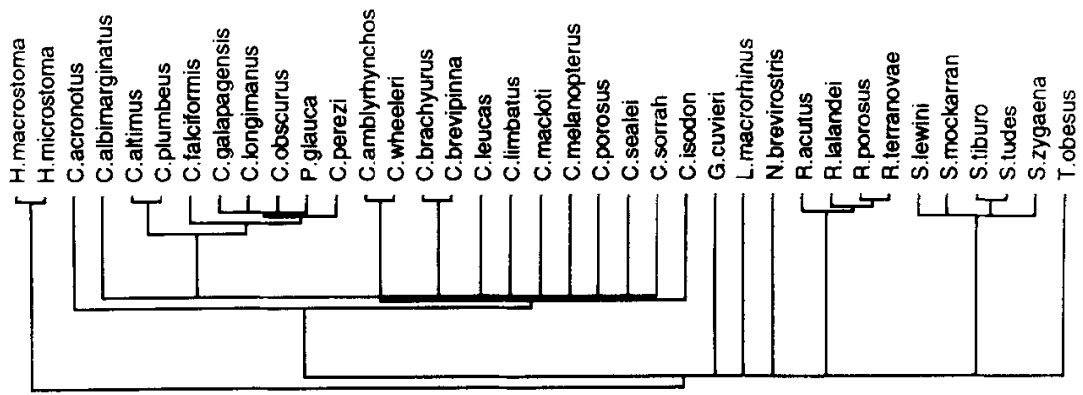

Fig. 3. (a) Majority rule consensus tree of the first 20000 MPTs generated by branch swapping on seed A. (b) Semi-strict consensus tree of the first 20000 MPTs generated by branch swapping on seed A. (c) Semi-strict consensus tree of successively weighted trees generated by branch swapping on seed $\mathrm{A}$. Final (asymptotic) weights used are given in Appendix 2b. (Note that the semi-strict consensus is more resolved for the successively weighted trees than it is for the unweighted trees.) 
as seen in the unweighted analysis. However, while the within-tree set distances are comparable to those seen for the unweighted case, the among-tree set distances are roughly half those seen for the unweighted case. Invoking Maddison's (1991) "islands of trees" analogy once again, it would appear (for this data set at any rate) that successive weighting has drawn islands in the "archipelago" closer together without affecting their size.

(a) Majority rule consensus - No weighting

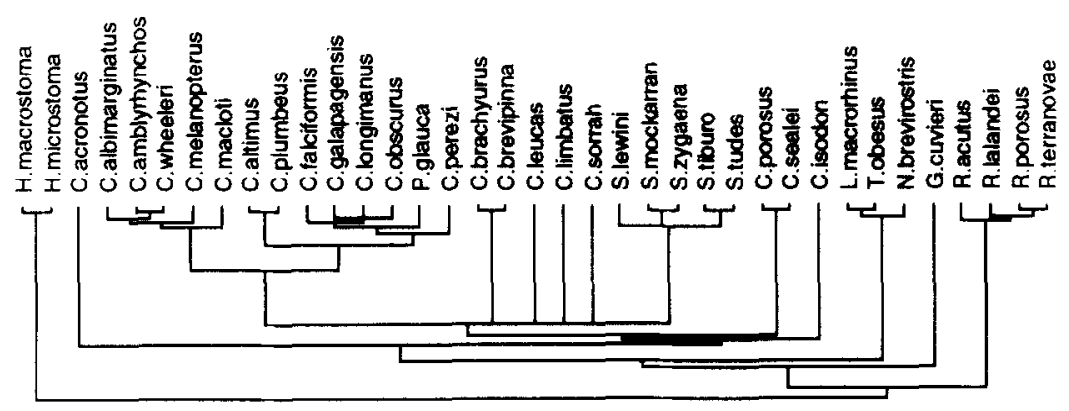

(b) Semi-strict consensus - No weighting

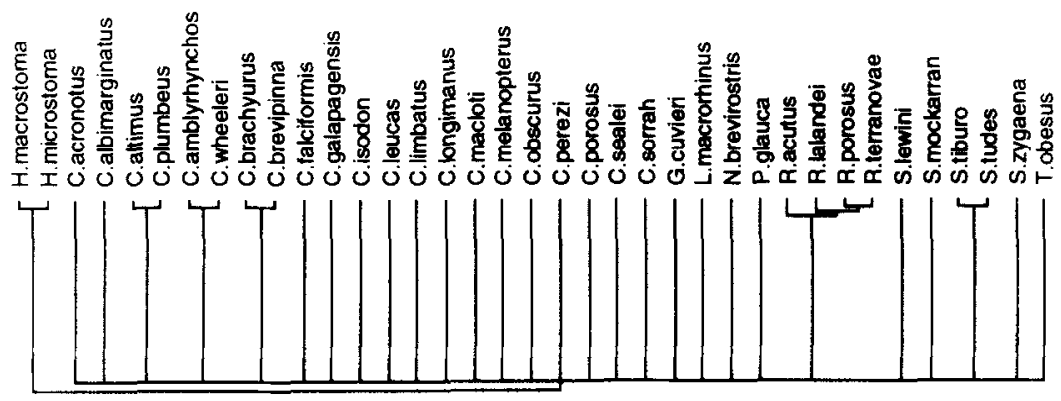

(c) Semi-strict consensus - Successive welghting

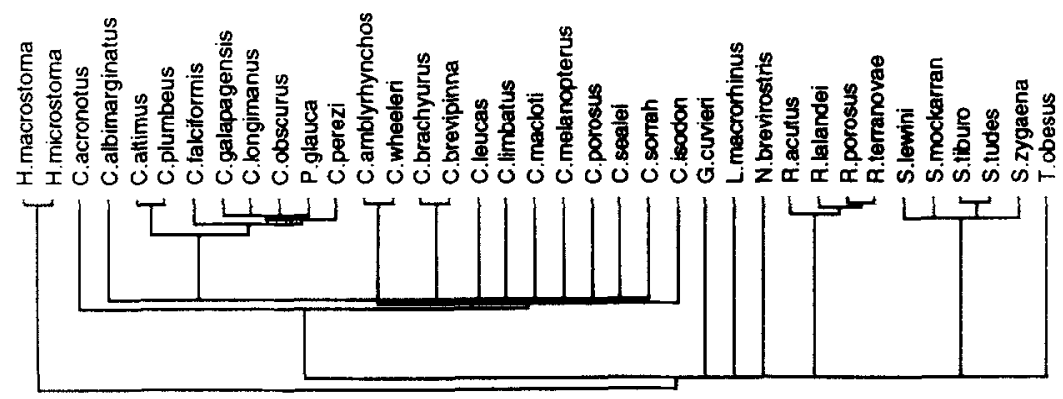

Fig. 4. (a) Majority nule consensus tree of the first 20000 MPTs generated by branch swapping on seed B. (b) Semi-strict consensus tree of the first 20000 MPTs generated by branch swapping on seed B. (c) Semi-strict consensus tree of successively weighted trees generated by branch swapping on seed B Final (asymptotic) weights used are given in Appendix 2b. Note that the topology for Fig. 5 (c) is the same as that of Fig. 4(c), reflecting the convergence of tree topologies toward the same solution. 

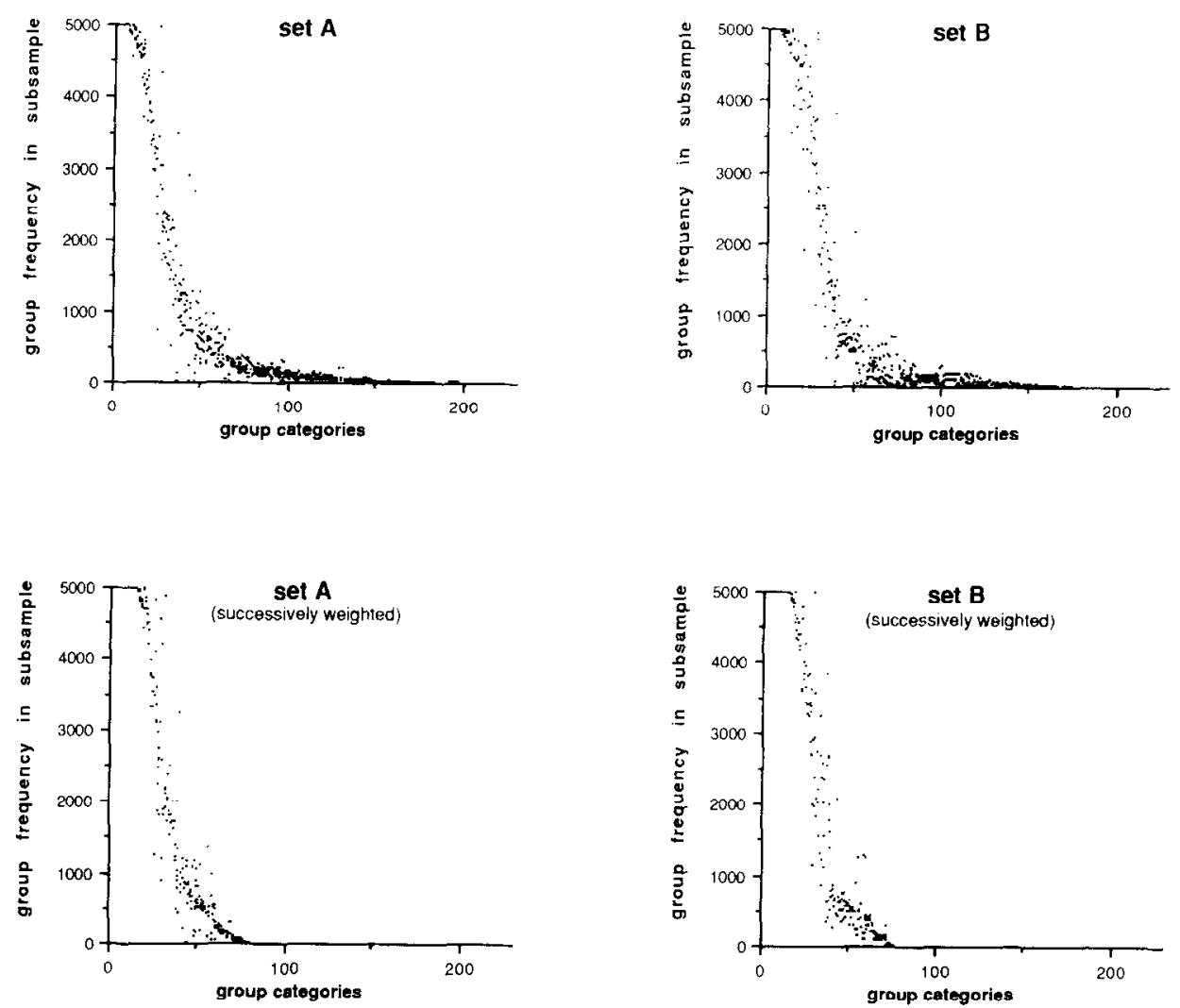

Fig. 5. Hierarchical signal consistency among sub-samples of trees. Each plot depicts the frequencies of corresponding groups (clades) found in each of four sub-samples. Each sub-sample comprised 5000 trees $(1-5000,5001-10000,10001-15000,15001-20000)$. Note that the curves produced by successive weighting have characteristically extended plateau regions and truncated tails, reflecting, respectively, an increased number of clades found in $100 \%$ of the trees and a decreased number of rare clades found among all the trees. Both factors cause the strict consensus tree derived from successively weighted trees to be more resolved.

The semi-strict consensus of the successively weighted analysis was chosen as the most reliable summary of the phylogenetic signal in the data on the grounds that it was: (a) uninfluenced by seed tree bias; and (b) the most resolved tree that was entirely consistent across all sub-samples (the majority rule trees varied across subsamples for some of the groupings found).

\section{VARIATION BETWEEN ANALYSES}

While the retention indices for the MPTs generated in the parsimony analysis are high (0.892) and the cophenetic correlation coefficient is high for the distance Wagner tree, the conclusions concerning relationships vary between analyses. The semi-strict consensus tree derived from the successively weighted character analysis is much less resolved than is the distance Wagner tree. This is largely because the semi-strict consensus tree is a particularly stringent summary of the MPTs found. As a result, there are clades found in the distance Wagner tree that appear unresolved in the semi-strict consensus tree, but that are supported by a large percentage of 
the MPTs used to generate the semi-strict consensus. At the risk of seeming too conservative, only those groups found in the semi-strict consensus tree of the successively weighted tree sets are regarded here as phylogenetically reliable.

The relationships within genera other than Carcharhinus tend to be consistent between analyses. Hammerhead sharks (Sphyma) and sharpnose sharks (Rhizoprionodon), for example, fall into distinct monophyletic clades in all trees and have a high degree of within-clade topological congruence between analyses. Relationships among genera also show some concordance. Galeocerdo (the tiger shark), Rhizoprionodon, Sphyma, Loxodon (the slit-eye shark), Negaprion (the lemon shark) and Triaenodon (the reef white-tip shark), are placed outside Carcharhinus in all trees. Rhizoprionodon and Galeocedro, are placed basally on the distance Wagner tree. This resolution is not seen in the semi-strict consensus tree of the successively weighted character analyses. However, this basal placement was found in $95 \%$ of the MPTs that were used to generate the consensus tree.

Relationships within Carcharchinus vary considerably between analyses. Some species pairs are defined in both trees, i.e. [C. amblyrhynchos-C. wheeleri]. [C. plumberusC. altimus], [C. brevipinna-C. brachyurus]. But there are disagreements about relationships among these sub-groups.

The placement of the blue shark Prionace glauca is problematic. If $P$. glauca is omitted, then the genus Carcharhinus forms a monophyletic group in both analyses. However, when $P$. glauca is included, it falls in a clade containing (. obscumes, $C$. galapagensis and $C$. longimanus in the character analysis but as the sister taxon to the clade containing the genera Carcharhinus, Loxodon, Negaprion and Triaenodon in the distance Wagner analysis. Interestingly, if $P$. glauca is excluded from the Carcharhinus clade using the constraints option of PAUP, there is no increase in the number of steps required (in the unweighted implementation). If the weights derived from successive weighting are implemented, then the exclusion of $P$. glauca from the Carharhinus clade results in an increase in tree length from 61664 to 6215.3 $(0.79 \%$ increase in length). $P$. glauca is autapomorphic at eight of the presumed loci scored (Appendix 2a). This suggests that, if it is indeed a derived member of the genus Carcharhinus, it has experienced accelerated molecular evolution relative to its sister taxa. Given that $P$. glauca is autapomorphic at so many loci and given that its placement outside Carcharhinus does not require extra steps in the unweighted implementation, and causes less than $1 \%$ increase in tree length in the weighted implementation, it may be premature to make systematic statements based on parsimony as to its true phylogenetic position. However, it is noteworth that independent morphological and fossil evidence support the idea that the blue shark might be a derived speries within the genus Carcharhinus. Compagno (1988) suggests that its broad serrated teeth link $P$. glausa to the obscurus group of sharks. Similarly teeth referable to Carcharhinus first appear in the Middle Eocene (Stromer, 1905), whereas teeth referable to Pronace do not appear until the Pliocene (Landini, 1977). If indeed Prionace is not a derived member within Carcharhinus but rather the sister group a clade containing Carcharhimus, I.oxodm Triaenodon, Negaprion, as suggested by the distance Wagner analysis, then the conspicuous absence of its fossil teeth during the Eocene. Oligocene, and Miocenc must be explained. (One explanation is of course, that $P$. glauca is the modern descendant of an old lineage that did not develop its unique tooth morphology until the Pliocene.) 


\section{(a) PARTITION METRIC DISTANCES BETWEEN \\ MAJORITY RULE CONSENSUS TREES \\ (DERIVED FROM UNWEIGHTED DATA SET)}

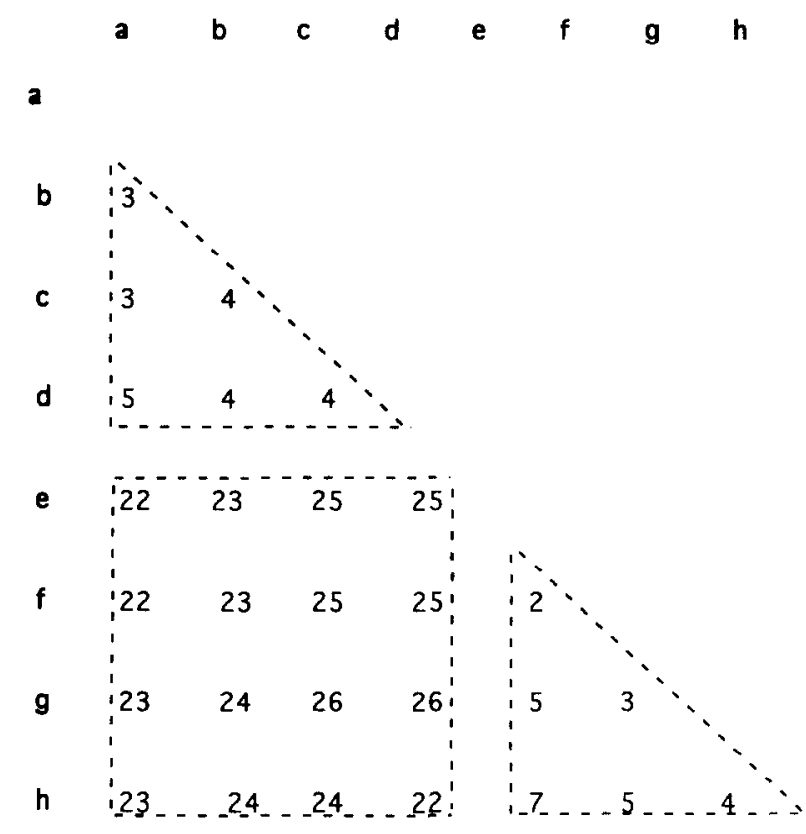

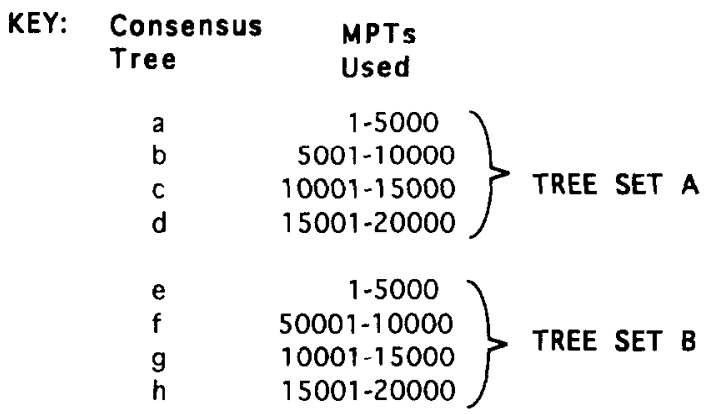

Fig. 6. (a) Partition metric distances (Penny and Hendy, 1985) among majority rule trees constructed from sub-samples of trees generated by branch swapping on unweighted data sets. Trees a to d are derived from branch swapping on seed tree "A", while trees e to $h$ are derived from branch swapping on seed tree "B". The partition distances show that groups of trees derived by branch swapping on a given seed tree are more similar to one another (triangular outlines) than they are to trees generated from a different seed (rectangular outline). This observation is concordant with Maddison's (1991) finding of islands of trees.

\section{Correspondence to the Stratigraphic Sequence}

The remainder of the discussion addresses the tree topology depicted in the semi-strict consensus tree of successively weighted trees [Figs 3(c) and 4(c)]. Because carcharhiniform sharks have such an excellent fossil tooth record (Maisey, 1984) the first recorded stratigraphic appearance of each taxon is presented to 
(b) PARTITION METRIC DISTANCES BETWEEN

MAJORITY RULE CONSENSUS TREES

(DERIVED FROM SUCCESSIVELY WEIGHTED DATA SET)
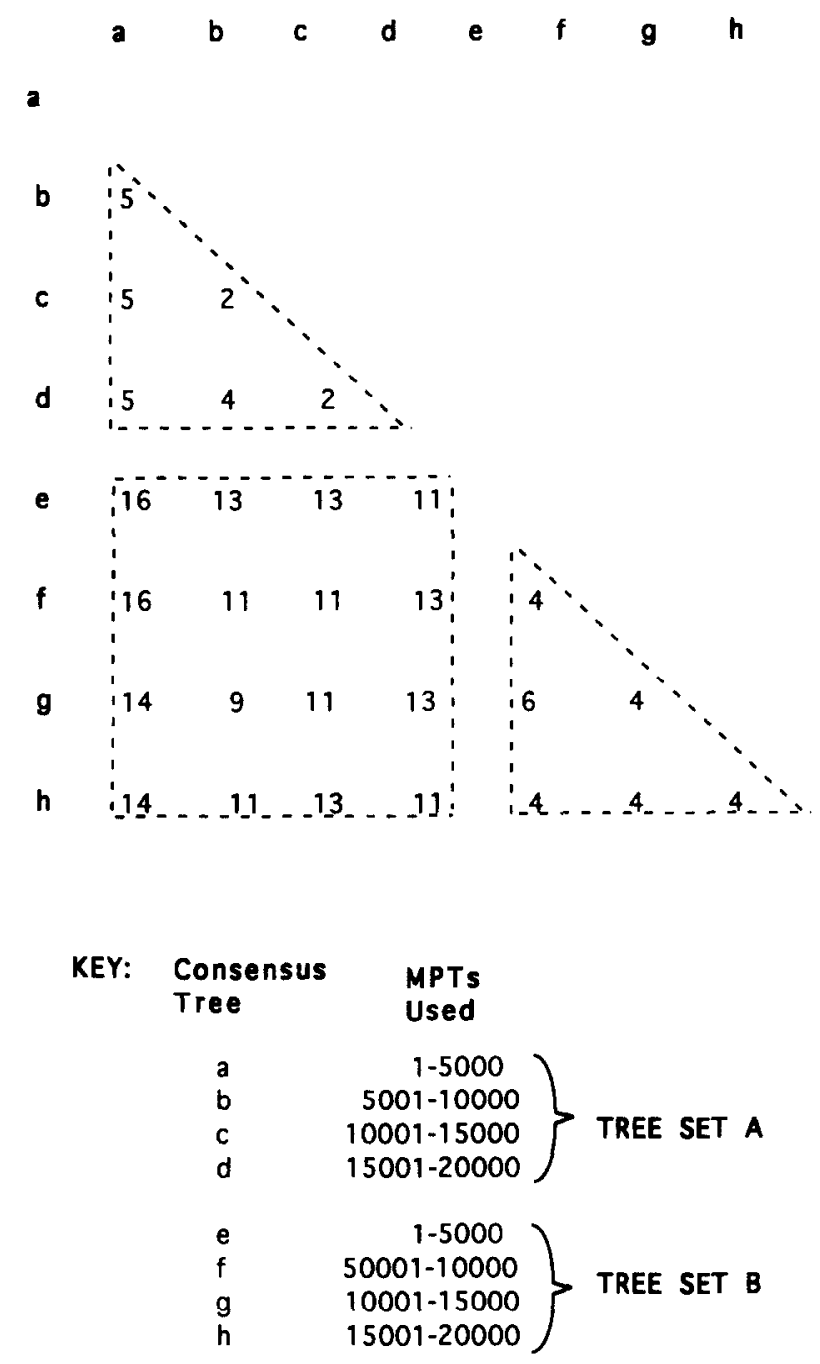

Fig. 6. (b) Partition metric distance (Penny and Hendy, 1985) among majority rule trees constructed from sub-samples of trees generated by branch swapping after asymptotic successive weighting. Trees a to $d$ are derived from branch swapping on seed tree "A", while trees $e$ to $h$ are derived from branch swapping on seed tree " $B$ ". The partition distances show groups of trees derived by branch swapping on a given seed tree to be more similar to one another than to trees generated from a different seed. Note, however, than the partition distances between different tree sets are considerably smaller for the successively weighted case than they are for the unweighted case depicted in Fig. 6(a).

determine whether the cladogram branching sequence is concordant with first appearance times.

The tiger shark Galeocerdo cuvieri emerges as one of seven polytomous branches most basal to the selected outgroup Hemigaleus. As mentioned previously, Galeocerdo and Rhizoprionodon form the two most basal branches in $95 \%$ of the successively weighted MPTs, perhaps suggesting a more basal position for these two taxa than 
actually depicted in the semi-strict consensus tree. Fossil teeth of Galeocerdo are first recorded from the Ypresian (Lower Eocene) of Morocco (Arambourg, 1952; Capetta, 1981; Capetta, 1987).

The four species of sharpnose sharks Rhizoprionodon form a distinctly monophyletic cluster branching from the polytomy. Rhizoprionodon shares two primitive morphological traits with Galeocerdo: long labial furrows and pre-anal ridges (Compagno, 1988). None of these characters occurs in the more derived taxa. The basal placement of Rhizoprionodon is consistent with the early appearance (Lower Eocene, Capetta, 1987) of its teeth in the fossil record. The branching sequence within the Rhizoprionodon clade is corroborated by morphology. $R$. porosus and $R$. terranovae are sibling species distinguishable only by vertebral counts. I' $h$ is pair have many cranial similarities with $R$. lalandii while all three are markedly distinct from the largely circumtropical and relatively primitive $R$. acutus.

The hammerhead sharks (Sphyrnidae) form a clearly monophyletic group branching from the same seven branch polytomy. The earliest fossil teeth of Sphyma are recorded from the Lower Miocene (Capetta, 1987). It is possible, however, that small sphyrnid teeth found at earlier fossil horizons have been incorrectly identified either as Physogaleus, Scoliodon or Rhizoprionodom due to their strikingly similar shapes. If this is the case, then the origin of sphyrnids might be older than is currently supposed from fossil tooth evidence. Compagno (1988) makes a convincing argument for the development of the hammerheads from a Scoliodon or Rhizoprionodon-like ancestor. He suggests that the lateral trowel-like flanges on the snout of Scoliodon might represent the vestige of an incipient hammerhead cephalofoil. This in conjunction with the very similar tooth shape between hammerheads and Rhizoprionodon and Scoliodon (Capetta, 1987; Compagno, 1988; pers. obs.) would be consistent with the origin of sphyrnids occurring at any time subsequent to the origin of Rhizoprionodon or Scoliodon. Within the hammerheads, the two diminutive species Sphyma tiburo and $S$. tudes form a sub-clade.

The slit-eye shark, Loxodon macrorhinus, the reef white-tip shark, Triaenodon obsesus and the Lemon shark, Negaprion brevirostris, all branch independently at the same polytomous hierarchical level as Galeocerdo, Rhizoprionodon and Sphyma. Teeth from I.oxodon are so similar to those of Rhizoprionodon and Scoliodon, both in size and shape that reliable first appearances in the fossil record have not yet been established (Capetta, 1987). Teeth from Triaenodon are quite small and to my knowledge have not been reported in the fossil record. Teeth from Negaprion first appear in the Middle Eocene of Nigeria (White, 1955).

The genus Carcharhinus comprises a large clade that appears to include $P$. glauca. Fossil Cacharhinus teeth are first recorded from the Middle Eocene of Egypt (Stromer, 1905). The species most commonly recorded in the fossil record from this period onward is the C. leucas-like C. egertoni (Capetta, 1987).

\section{Relationships within the Clade Containing Carcharhinus and Proonace}

Relationships within the genus Carcharhinus are only partially resolved. C. acronotus is placed as the sister taxon to all other members of the genus. C. isodon branches next, after which there is then a polytomy containing 11 branches. Eight of these 11 branches give rise directly to terminal taxa. Two of the branches give 
rise to the species pairs (C. brevipinna, C. brachyumus) and (C. amblyrhynchos, C. wheeleri). One branch gives rise to an internally well-resolved clade containing eight taxa.

All eight sharks in this resolved clade are large, growing to more than $2 \mathrm{~m}$ total length. All but one of the eight $(P$. glauca) have an interdorsal ridge running longjtudinally between the two dorsal fins. Within the clade. $C$. altimus and $C$. plumbeus branch off basally as a species pair. The silky shark, $C$. falciformis, branches off next, followed by $C$. perezi, which forms the sister taxon to an apical polytomous clade containing $C$. galapagensis, $C$. obscurus, $C$. longimanus and $P$. glauca.

\section{PrFVIOUSLY PROPOSED INTERRELATIONSHIPS WITHIN CARCHARHINIS}

Springer $(1950,1951)$ suggested that Carcharhinus sensu lato might be divided into smooth-backed forms (Carcharhinus sensu siricto) and ridge-backed forms. He suggested in turn that the ridge-backed forms should be divided into those with pointed first dorsal and pectoral tips (Eulamia) and those with rounded tips Pterolamniops. This treatment was abandoned as it was considered that both his ridge-backed and smooth-backed groups necessitated the inclusion of species 100 diverse in other characters to be aligned with each other (Garrick, 1982). Carrick proposed that $C$. obscurus and $C$. galapagensis might be regarded as the central members of a group which included $C$. altimus, $(\therefore$ plumbers, $C$. perezi and C. longimanus. This group, which he referred to as the obscumes group, was erected to include large ridge-backed sharks that had, for the most part, broad triangular teeth (C. perezi excepted). Garrick (1982) thus excluded C. sorrah, C. falciformis, C.. allomarginatus and C. sealei from Springer's Eulamia group but included C. longimanus, in spite of its distinct rounded fin morphology. Compagno (1988) concurred with Garrick's assessment except that he removed (.: perezi from the group and included C. albimarginatus. The allozyme data presented here suggest that the large ridgebacked members of the genus (C. obscurus, (.. galapagensis, C. longimanus, (.: faliformis, C. plumbeus, C. altimus and C. perezi) are all members of a monophvletic group that also includes $P$. glauca.

Garrick (1982) and Compagno (1988) have postulated several other tentative sub-groupings within Carcharhinus based on morphological similarity. Both Garrick (1982) and Compagno (1988) suggest that $(:$ porosus should be closely linked to the C. dussumeri-C. sealei group. This close relationship is supported by the distance Wagner tree but does not appear in the semi-strict consensus tree or the successively weighted character analysis. Compagno's inclusion of C. macloti and (. sorrah in this group is not supported.

Garrick suggested that C. albimarginatus was closely related to C. amblyrhynchos and $C$. wheeleri on the basis of overall morphology, tooth shape and vertebral characteristics. This suggested relationship is supported by the distance Wagner tree but does not appear in the semi-strict consensus tree. Compagno's treatment of $C$. perezi as the sister group to C. amblyrhynchos and C. wheeler is not supported.

The suggestion by both authors that the sibling species C. limbatus and $C$. amblyrhynchoides are most closely related to C. brevipinna is not supported. In this study, C. betipinna falls closest to $C$. brachyurus. The striking similarity between (i. limbatus and C. brevipinna in body shape, color pattern, tooth shape and behavior appears to be the result of convergent evolution rather than of close relatedness. Support for 
this supposition is seen in the disparate ontogenies of the two species with respect to color pattern. C. limbatus juveniles are born with distinctive black pigmented fin tips. These markings diminish in intensity with age so that large adults appear only diffusely pigmented (pers. obs.). In contrast, C. brevipinna juveniles are born unpigmented but develop an increasingly intensive black pigment on the fin tips with age (Garrick, 182), so that large adults often appear as though their fins had been dipped in black ink (pers. obs.).

The recent allozyme survey by Lavery (1992) is closely comparable to the present study. In his study, Lavery scored 38 allozyme loci for 21 taxa. Unfortunately, the two data sets cannot be readily combined to evaluate the total evidence for the phylogeny. Comparisons are thus restricted to topological

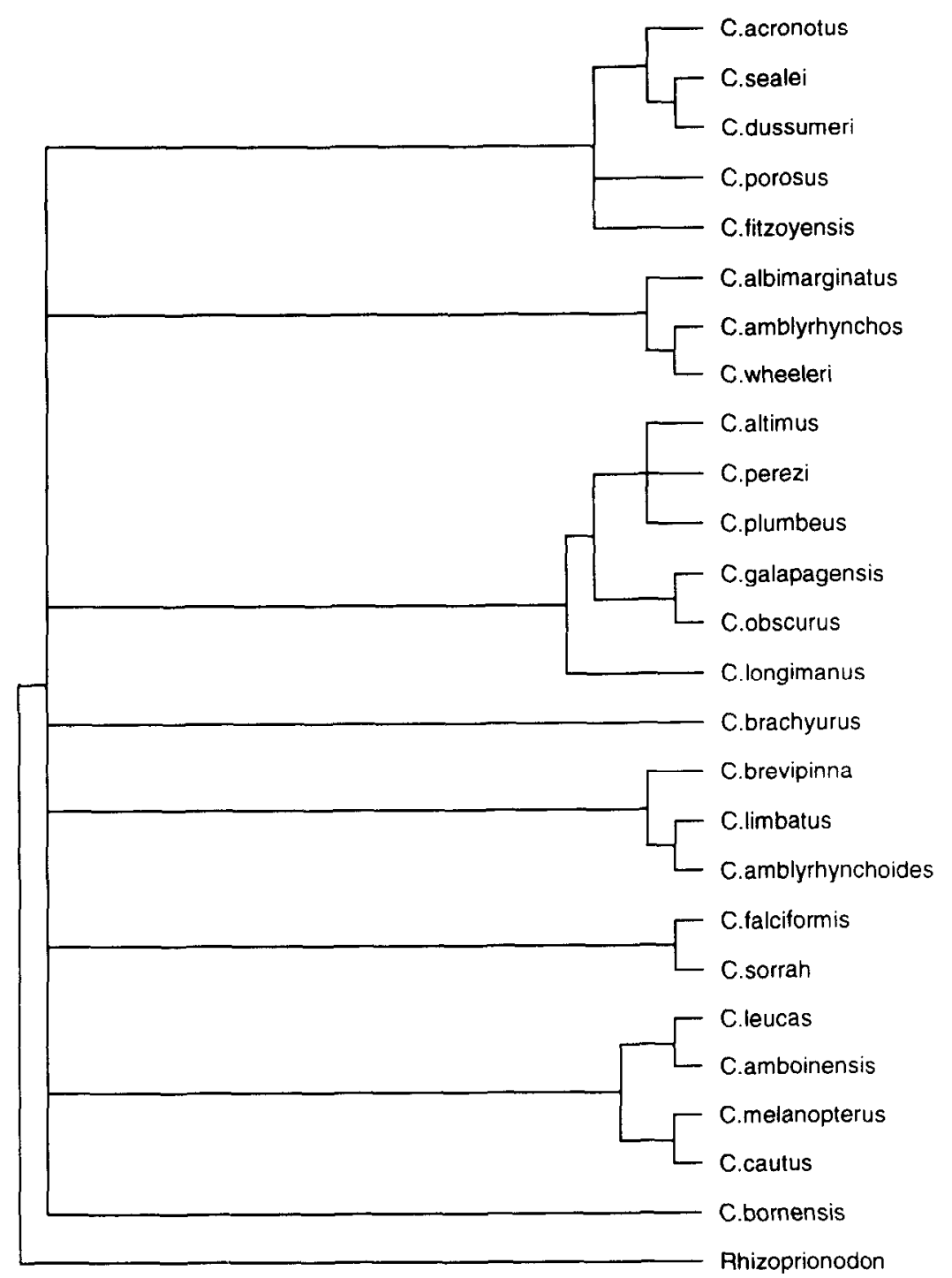

Fig. 7. Phylogenetic hypothesis for sharks of the genus Carcharhinus after Garrick (1982). Topology deduced from Garrick's text. 
similarities and differences among inferred trees. In Lavery's study, one most parsimonious tree resulted with a length of 215 steps and a retention index of 0.545. The monophyly of the genus Carcharhinus was not supported in his study. Instead, the genus was seen to be paraphyletic including members of two other genera (Negaprion acutudiens and Galeocerdo cuvieni) and one member of an entirely different family (Hemipristis elongatus). A re-analysis of Lavery's data shows that if the genus Carcharhinus is constrained to be monophyletic, five most parsimonious trees of length 219 steps result. This represents a four-step increase over his presented most parsimonious tree. (Lavery reported that "placing these three species in their recognized positions outside the genus Carcharhinus results in a tree

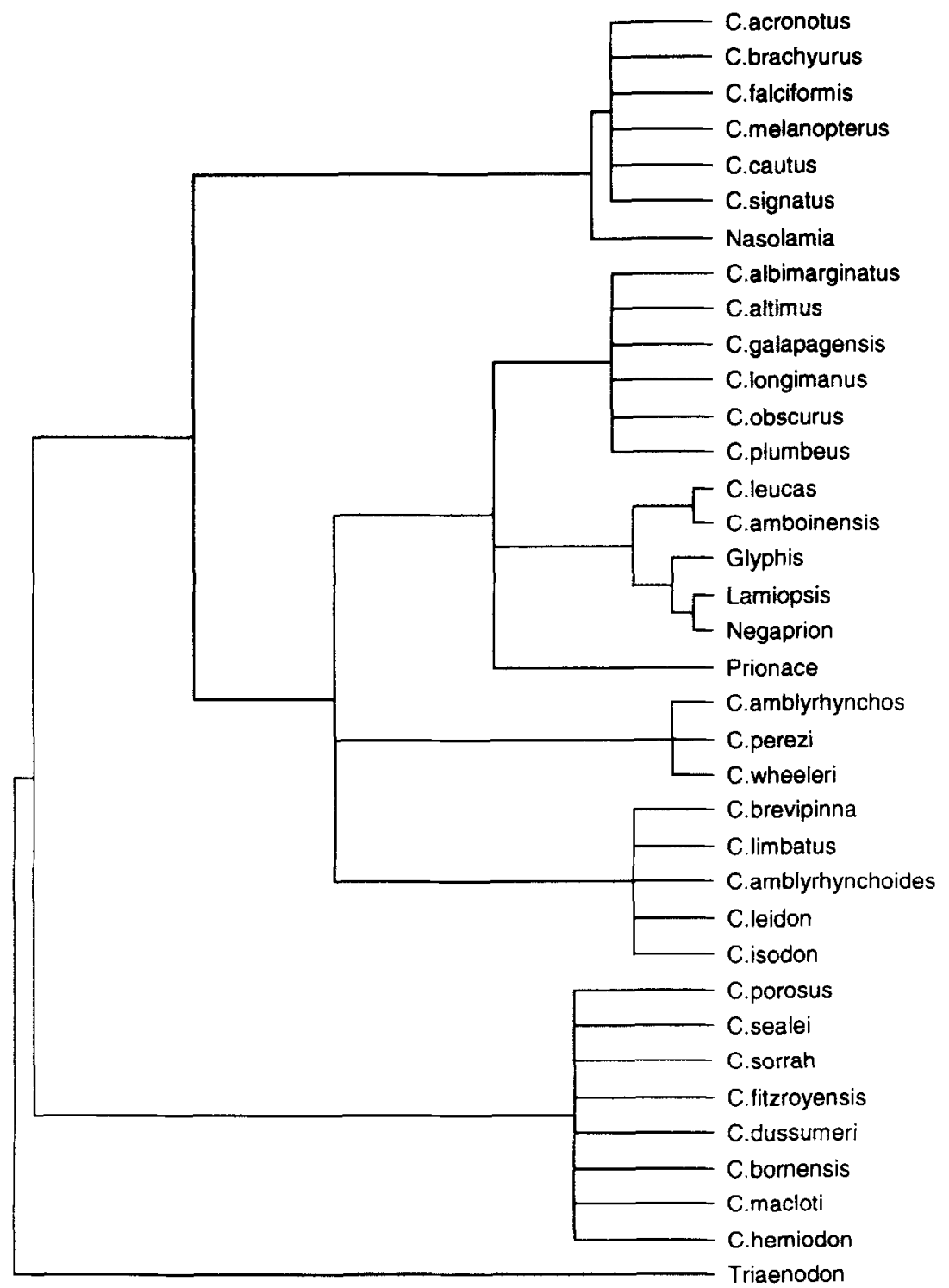

Fig. 8. Phylogenetic hypothesis for sharks of the genus Carcharhinus after Compagno (1988). Topology deduced from Compagno's text and presented cladogram. 
almost $10 \%$ longer [either 228 or 229 steps, depending on the precise arrangement]. I was unable to reproduce this finding). By reciprocal contrast, the inclusion of Negaprion brevirastris, Galeocerdo cuvieri and Hemigalenus within Carcharhinus in the present study results in an increase in tree length of two steps.

As pointed out by Lavery (1992), the two studies do not overlap extensively as they examine different portions of the Carcharhinus phylogeny. A larger survey, polling the taxa from both studies, is recommended to more confidently assert phylogenetic structure within the genus Carcharhinus.

\section{Cl.ASSIFICATION}

Results from both the distance Wagner and character analysis indicate that the Carcharhinidae, as it now stands, is a paraphyletic group which includes the hammerhead sharks (genus Sphyma). Compagno (1988) proposed a tentative cladistic re-classification of the Carcharhinidae, based on morphological characters, in which the hammerheads were assigned to the tribe Sphyrnini within the Carcharinidae. As both the morphological data and the molecular data presented herein are in agreement, I suggest that Compagno's cladistic re-classification of hammerheads be adopted.

Proposals to subdivide the genus Carcharhinus have been made by Owen (1853), Gill (1962), Whitley (1934, 1939, 1943) and Springer (1950, 1951). Garrick (1982) suggested that "the prime reason for these taxa failing to become established in usage is that for the most part they were erected on the basis of only one species for each and without sufficient reference to, or distinction from, other known species." (Springer's division of Carcharhinus s.l. into two genera, Carcharhinus s.l. [smooth-backed forms] and Eulamia [ridge-backed forms] is excepted.)

Results of this study partially corroborate the tentative intra-generic affinities put forward by Garrick (1982). However, some of the groupings proposed are strongly analysis dependent and are only tenuously supported by the available data. If a classification is adopted that reflects the presented cladogram, ad hoc incidences of accelerated molecular evolution must be invoked to explain the data. Furthermore, because the hypothesized cladogram of relationships within the genus Carcharhinus shows a largely unresolved tree, any strictly monophyletic reclassification of the genus would involve naming several monotypic taxa. It is recommended that a formal re-classification of Carcharhinus be postponed until further evidence concerning relationships becomes available. DNA sequence data are currently being collected for this purpose.

\section{Acknowledgments}

Several people assisted in the collection of material for this study. I would particularly like to thank the commercial fishermen and scientists who either allowed me to accompany them fishing or actually collected specimens for me. They are: from the east coast of North America: D. De Maria, R. Bakey, E. Sanders, N. Sanders, J. Musick and J. Colvocoresis; from Hawaii: E. Schellenburger, S. Kaiser and M. Suiso; from the Red Sea: A. Sulliman and "Muhammed". Others who generously provided either direct assistance or advice were R. Apilado, "Mungpert" and D. Cadra (Philippines), J. Parrish and Sea Life Park (Hawaii), P. Coutin 
and P. Showers (Sierra Leone), R. Fox, D. Doubilet and H. Fraise (Australia), M. Doty, L. Cohen, T. Bowman (Belize), S. Blum, J. Casey, R. Shipp, J. Dendo, G. Nelson, L. Abele, V. Springer, G. Burgess, J. Castro, J. Ott, E. Silverfine, D. Carr, J. Jibrin, S. Wilkes, S. Fitzgerald, D. Chipman and E. Knurek (U.S.A.).

I thank Carla Hass for patiently teaching me electrophoretic techniques and E. Clark, M. Doty, R. Highton, C. Miter, G. Vermeij, R. Voss, G. Wilkinson and four anonymous reviewers for their helpful suggestions for the improvement of the manuscript. I would likc to give spccial thanks to R. Highton for the use of his electrophoresis laboratory, to G. Vermeij for his persistent encouragement and to E. Clark for first suggesting I pursue this project. Financial support was provided by The WIN Foundation, The University of Maryland Foundation, The University of Maryland Computer Science Center, D. Shen and the National Science Foundation (grant BSR 87-08121 to G. J. Vermeij and grant BSR 83-07115 to R. I Jighton).

\section{REFERENCES}

ArambourG, C. 1952. Les vertebres fossiles des gisements de phosphates (Maroc-AlgerieTunisie). Serv. Geol. Maroc, Notes et Mem. 92: 1-372.

ARCHIE, J. W. 1989. A randomization test for phylogenetic information in systematic data, Syst. Zool. 38: 239-252.

Baranes, A. And O. Shahrabany-Baranes. 1986. A numerical taxonomic study of the northern Red Sea carcharhinids. Proc. 2nd Int. Conf. Indo-Pacific Fishes, pp. 246-255.

Bigfiow, H. B. And W. C. Schroeder. 1948. Fishes of the western North Atlantic. Part 1. Mem. Sears Found. Mar. Res. Yale Univ. Press, New Haven, Connecticut.

CAPETTA, H. 1981. Additions a la faune de selaciens fossiles du Maroc. 1: sur la presence des genres Heptranchias, Alopias et Odontorhytis dans I'Ypresien des Ouled Abdoun. Geobios 14: 563-575.

CAPETTA, H. 1987. Chondrichthes II. Mesozoic and Cenzoic Elasmobranchii. Vol. 3b. Handbook of Paleoichthyology. Gustav Fischer Verlag, Stuttgart, West Germany.

CARPENTER, J. M. 1988. Choosing among multiple equally parsimonious cladograms. Cladistics 4: $291-296$.

CAVAl. I-SFORZA, L. L. AND W. F. EdWARds. 1967. Phylogenetic analysis: Models and estimation procedures. Evolution 21: 550-570.

Compagno, L. J. V. 1984. FAO species catalogue. Vol. 4. Sharks of the world. An annotated and illustrated catalogue of shark species known to datc. Part 2. Carcharhiniformes. FAO Fish. Synop. 125: 251-655.

Compagno, L. J. V. 1988. Sharks of the Order Carcharhiniformes. Princeton Univ. Press. Princeton, New Jersey.

FARRIS, J. S. 1969. A successive approximation approach to character weighting. Syst. Zool. 18: 256-268.

Farris, J. S. 1972. Estimating phylugenetic trees from distance matrices. An. Natt. 106: 645-668.

FarRIS, J. S. 1989. The retention index and the rescaled consistency index. (ladistics 5: 417-419.

Garrick, J. A. F. 1982. Sharks of the genus Carcharhinus. NOAA. Tech. Rep., NMFS. Cirr. 445.

Gakkick, J. A. F. 1985. Additions to a revision of the shark genus Carcharhinus: Synonvmy of Aprionodon and Hypoprion, and description of a new species of Carcharhinus. NOAA Tech. Rep., NMFS. Circ. 34.

GiLl., T. 1862. Analytical synopsis of the order of squati: and revision of the nomenclature of the genera. Ann. Lyceum Nat. Hist. 7: 367-408.

Harris, H. AND D. A. Hopkinson. 1976. Handbook of Enzyme Electrophoresis in Human Genetics. North Holland Publishing, Amsterdam, The Netherlands. 
HEDGES, S. B. 1986. An electrophoretic analysis of holarctic hylid frog evolution. Syst. Zool. 35: 1-21.

LANDINI, W. 1977. Revizione degli ittiodontoliti pliocenici della collezione Lawley. Palaeontographia Italica. 70: 92-134.

LAVERY, S. 1992. Electrophoretic analysis of phylogenetic relationships among australian carcharhinid sharks. Aust. J. Mar. Freshwater Res. 43: 97-108.

MADDISON, D. R. P1991. The discovery and importance of multiple islands of most-parsimonious trees. Syst. Zool. 40: 315-328.

MAISEY, J. G. 1984. Higher elasmobranch phylogeny and biostratigraphy. Zool. J. Soc. 82: 33-54.

Margush, T. AND F. R. MCMORRIS. 1981. Consensus n-trees. Bull. Math. Biol. 43: 239-244.

NAYLoR, G. J. P. 1992. Plotting frequency distibutions of Phylogenetic groupings found among sets of most parsimonious trees. Cladistics 8: 161-164.

NomenClature COMmitTeE OF THE InTERnational Union of Biochemistry. ed. Enzyme Nomenclature 1978. Academic Press, New York.

OWEN, SIR RICHARD. 1853. Descriptive Catalogue of the Osteological Series Contained in the Museum of the Royal College of Surgeons of England, Vol. 1. Taylor and Francis, London

PENNY, D. AND M. D. Hendy. 1985. The use of tree comparison metrics. Syst. Zool. 34: 75-82.

Prager, E. M. AND A. C. Wilson. 1976. Congruency of phylogenies derived from different proteins. A molecular analysis of the phylogenetic position of cracid birds. J. Mol. Evol. 9: 45-57.

Richardson, B. J., P. R. Baverstock and M. Adams. 1986. Allozyme Electrophoresis. A Handbook for Animal Systematics and Population Studies. Academic Press, Orlando, Florida.

Selander, R. K., M. H. Smith, S. Y. Yang, W. E. Johnson, AND J. B. Gentry. 1971. Biochemical polymorphism and systematics in the genus Peromyscus. I. Variation in the old-field mouse (Peromyscus polionotus). Stud. Genet. VI. Univ. Texas Publ., 7103: 49-90.

Shaw, C. R. AND R. PRASAD. 1970. Starch gel electrophoresis of enzymes-a compilation of recipes. Biochem. Genet. 4: 297-320.

Siclliano, M. J. AND C. R. SHaw. 1976. Separation and visualization of enzymes on gels. In I. Smith (ed.). Chromatographic and Electrophoretic Techniques, Vol. 2, Fourth edn. Heinemann, London, pp. 185-209.

SPRINGER, S. 1950. A revision of North American sharks allied to the genus Carcharhinus. Amer. Mus. Nov., 1451; 1-13.

SPRINGER, S. 1951. Correction for "A revision of North American sharks allied to the genus Carcharhinus". Copeia 3: 244.

Stromer, E. 1905. Die fischreste des mittleren und oberen eocans von Agypten. Beitr. Pal. Oesterr. 18: 37-58, 163-92.

SwOFFord, D. L. 1990. Phylogenetic Analysis Using Parsimony (PAUP), version 3.0k. Computer software. Illinois Natural History Survey, Champaign.

WHITE, E. I. 1955. On Lyamna eurybathrodon. Blake. Ann. Mag. Nat. Hist. 8: 191-193.

WhITLEY, G. P. 1934. Notes on some Australian sharks. Mem. Queensl. Mus. 10: 180-200.

WhITLEY, G. P. 1939. Taxonomic notes on sharks and rays. Aust. J. Zool. 9: 227-262.

WhitLEY, G. P. 1943. Ichthyological descriptions and notes. Proc. Linn. Soc. N.S.W., Sydney. 


\section{Appendix 1. Material Examined}

Carcharhinus acronotus: 454791, 60516.3 (LORAN), Charleston, S. Carolina, N. America (372, 391); Bulls Bay, Nr Charleston, S. Carolina, N. America (373); Dauphin Is., Alabama, N. America (163); Mayport, Jacksonville, Florida, N. America (442).

Carcharhinus albimarginatus: Mercedes, Camarines Norte, Philippines (287)

Carcharhinus altimus: Norfolk Canyon, 60 miles east of Virginia Beach, N. America $(110,111,116,122,569)$.

Carcharhinus amblyrhynchos; Mercedes, Camarines Norte, Philippines (288, 289); Nihoa Island, (N. W. Hawaiian Islands), Hawaii (545); Tumalutab Is., Zamboanga City, Mindanao, Philippines (327, 328).

Carcharhinus brachyurus; Saint Kilda, Vincent Gulf, S. Australia (003).

Carcharhinus brevipinna; Mayport, Jacksonville, Florida, N. America (433); Ponce Inlet, Daytona, Florida, N. America (445, 450, 452, 461).

Carcharhinus falciformis: Moro Gulf: S. of Mindanao (via Arena Blanco, Zamboanga), Philippines (329, 330, 332, 333, 339); Port of Spain fish mkt, Trinidad $(474,506,506,508,509)$.

Carcharhinus galapagensis: Kaena Point, Oahu, Hawaii (128, 130, 132); Nihoa Island, (N. W. Hawaiian Islands), Hawaii (544); seaward side of Rabbit Island, Oahu, Hawaii (572).

Carcharhinus isodon: Bulls Bay, Nr Charleston, S. Carolina, N. America (409. 410, $411,411 \mathrm{a}, 411 \mathrm{~b})$.

Carcharhinus leucas; Dauphin Is., Alabama, N. America (100); Mayport, Jacksonville, Florida, N. America (436); Ponce Inlet, Daytona, Florida, N. America $(457,458)$; sand shoal inlet, eastern shore, Virginia, N. America (370).

Carcharhinus limbatus: Dauphin Is., Alabama, N. America $(154,156)$; Ponce Inlet, Daytona, Florida, N. America $(444,446)$; sand shoal inlet, eastern shore, Virginia, N. America (368).

Carcharhinus longimanus: 1910 N, 16051 W (off Hawaii) (574); 1915 N, 16049 W (off Hawaii) (541, 542, 543); off Nihoa Island, (N. W. Hawaiian Islands), Hawaii. (573).

Carcharhinus macloti: Turtle Islands, Sulu Sea. (Navotas mkt, Manila), Philippines (284).

Carcharhinus melanopterus: Anda, Pangasinan. (Alaminos mkt), Philippines (261, 262); Straights of Tiran, Gulf of Aqaba, Red Sea (005, 006).

Carcharhinus obscurus: Dauphin Is., Alabama, N. America (95, 99); Norfolk Canyon, off Virginia Beach, Virginia, N. America (567, 568); Ocean City, Maryland, N. America (246).

Carcharhinus perezi: Deep Water Caye, Grand Bahama Is., Bahamas $(233,234,235)$; Glover's Reef, Dangriga, Belize $(179,180)$.

Carcharhinus plumbeus: Makapu Point, Oahu, Hawaii $(555,556)$; Maunalua Bay, S. Oahu, Hawaii (570, 571); Mayport, Jacksonville, Florida, N. America (437).

Carcharhinus porosus: Manzanilla Bay, eastern Trinidad (495, 496, 497, 498, 499).

Carcharhinus sealei: Turtle Islands, Sulu Sea. (Navotas mkt., Manila), Philippines $(273,274,275,276,277)$.

Carcharhinus sorrah: Navotas mkt, Manila, Philippines (origin probably Palawan) (259, 358); S. China Sea coast of Palawan (Navotas mkt Manila), Philippines (296, 297); Turtle Islands, Sulu Sea. (Navotas mkt, Manila), Philippines (300). 
Carcharhinus wheeleri: El Tur, South Sinai (in Straits of Tiran), Egypt (004); South side of Tiran Is. at "Melba" Egypt (008).

Galeocerdo cuvieri: Dauphin Is., Alahama, N. America (248); Makapu Point, Oahu, Hawaii $(552,553,554)$; Ocean City, Maryland, N. America (239).

Hemigaleus macrostoma: Turtle Islands, Sulu Sea. (Navotas mkt, Manila), Philippines $(314,315,316,317,318)$.

Hemigaleus microstoma: Visayan Sea. (Cebu City mkt), Philippines (324, 325).

Loxodon macrorhinus: Navotas Fish landing, Manila, Philippines (258); Turtle Islands, Sulu Sea. (Navotas mkt, Manila), Philippines (285, 285).

Negaprion brevirostris: off Cosgrove, Florida Keys, Florida, N. America (558, 560); Panama City, Florida, N. America (75).

Prionace glauca: 1915 N, 16049 W. (200 m SSW of Oahu, Hawaii (540); Point Pleasant, New Jersey, N. America (416).

Rhizoprionodon acutus: Freetown, (Sierra Fisheries by catch), Sierra Leone (215, 217); Turtle Islands, Sulu Sea, (Navotas mkt, Manila), Philippines (272, 312, 313).

Rhizoprionodon lalandii: Port of Spain fish mkt, Trinidad $(485,486,487,488,489)$.

Rhizoprionodon porosus: Port of Spain fish mkt, Trinidad (511).

Rhizoprionodon terranovae: 454791, 60516.3 (LORAN), Charleston, S. Carolina, N. America (375, 376, 390); Dauphin Is., Alabama, N. America (164).

Sphyma lewini: American Shoals, Florida Keys, Florida, N. America (539); Dauphin Is., Alabama, N. America (257); Ocean City, Maryland, N. America (245); Panama City, Florida, N. America (081).

Sphyma mockarran: Dauphin Is., Alabama, N. America (101, 256); Mayport, Jacksonville, Florida, N. America (443); Panama City, Florida, N. America (089, 090).

Sphyma tiburo: Manzanilla Bay, eastern Trinidad (500, 501).

Sphyma tudes: Manzanilla Bay, eastern Trinidad (502. 503, 504); Port of Spain fish mkt, Trinidad (491).

Sphyma zygaena: Ocean City, N. America (244).

Triaenodon obesus: Between Tiran and Sinafir Is., Gulf of Aqaba, Egypt (010); Nihoa Island, (N. W. Hawaiian Islands), Hawaii $(546,551)$; South side of Tiran Is., Egypt (009).

(Three-digit numbers in parentheses correspond to assigned field numbers) 
Appendix 2a. Character Matrix Based on Electromorph Differences, Including Autapomorphic States

\begin{tabular}{|c|c|c|c|c|c|c|c|c|c|c|c|c|c|c|c|c|c|}
\hline Presumed locus ${ }^{n}$ & 1 & 2 & 3 & 4 & 5 & 6 & 7 & 8 & 9 & 10 & 11 & 12 & 13 & 14 & 15 & 16 & 17 \\
\hline C. acronotus & F. & G & $\mathbf{K}$ & $\mathrm{F}$ & $\mathrm{K}$ & I & D & C & I & $\mathrm{E}$ & B & $\mathrm{D}$ & D & G & C: & (: & $A$ \\
\hline C. albimarginatus & $\mathbf{E}$ & $\mathrm{F}$ & M & K & $\mathrm{E}$ & $\mathrm{N}$ & $\mathrm{B}$ & D & J & G & B & $\mathrm{D}$ & $\mathrm{D}$ & 0 & $\mathrm{~F}$ & C & $A$ \\
\hline C. altimus & $\mathbf{E}$ & I & M & $\mathrm{F}$ & $\mathrm{K}$ & $\mathbf{N}$ & G & $\mathrm{C}$ & I & $\mathrm{H}$ & B & $F$ & $J$ & A & $\mathrm{F}$ & C: & A \\
\hline C. amblyrhynchos & $\mathbf{E}$ & C & $J$ & K & $\mathrm{D}$ & $\mathrm{N}$ & $B$ & C & I & (; & $\mathrm{C}$ & $\mathrm{D}$ & D & D & $\mathrm{F}$ & C & $A$ \\
\hline C. brachyurus & $\mathbf{E}$ & $\mathrm{F}$ & $\mathrm{Q}$ & $\mathrm{F}$ & $\mathrm{K}$ & $?$ & (; & C & I & G & B & D & D & B & J & H & $A$ \\
\hline C. brevipinna & $\mathbf{E}$ & $\mathrm{F}$ & $\mathrm{H}$ & $\mathrm{F}$ & $\mathrm{K}$ & $\mathrm{E}$ & $G$ & $\mathrm{C}$ & I & G & B & D & D & $\mathrm{E}$ & $\mathrm{F}$ & C: & A \\
\hline C. falciformis & $\mathbf{E}$ & $\mathrm{E}$ & $\mathbf{M}$ & $J$ & I & $\mathrm{E}$ & $\mathrm{k}$ & C & I & $\mathrm{D}$ & B & $\mathrm{F}$ & D & C & $\mathrm{H}$ & D) & $A$ \\
\hline C. galapagensis & $\mathbf{E}$ & $\mathrm{L}$. & $\mathbf{M}$ & J & I & $N$ & $\mathrm{~B}$ & $\mathrm{C}$ & I & $G$ & B & $\mathrm{F}$ & D & $\mathrm{K}$ & $\mathrm{F}$ & G: & $A$ \\
\hline C. isodon & $\mathbf{E}$ & G & $\mathbf{M}$ & G & $\mathbf{K}$ & $\mathrm{K}$ & $\mathrm{E}$ & C & I & G & $\mathrm{B}$ & $\mathrm{D}$ & D & I & $C_{i}$ & $G$ & $A$ \\
\hline C. Lenicas & C & $\mathrm{H}$ & $\mathbf{M}$ & $\mathrm{F}$ & $\mathrm{K}$ & $\mathrm{N}$ & $\mathrm{E}$ & $\mathrm{C}$ & I & G & B & D & D & $N$ & C; & C & $A$ \\
\hline C. limbatus & $\mathbf{E}$ & $\mathrm{H}$ & D & $\mathrm{F}$ & $F$ & $J$ & E & $\mathbf{F}$ & $\mathrm{H}$ & C: & $\mathrm{B}$ & I) & $n$ & $N$ & $\mathrm{~F}$ & C: & $A$ \\
\hline C. longimanus & $\mathrm{E}$ & $J$ & M & J & 1 & $\mathrm{~N}$ & B & G & 1 & G & $B$ & F & [) & K & $\mathrm{r}$ & 6 & $A$ \\
\hline C. macloti & $\mathrm{D}$ & A & I & $\mathrm{E}$ & L. & $\mathrm{N}$ & B & C & I & $;$ & B & D & D) & $s$ & $\mathrm{~F}$ & $\mathbf{E}$ & $\mathrm{A}$ \\
\hline C. melanopterus & $\mathrm{E}$ & $\mathrm{H}$ & $\mathbf{P}$ & $\mathrm{K}$ & $\mathrm{K}$ &.$v$ & $\mathrm{O}$ & C & I & G & B & D & I & $\mathrm{T}$ & $\mathrm{F}$ & 1 & 1 \\
\hline C. abscumis & $\mathrm{E}$ & $\mathrm{L}$ & $\mathbf{M}$ & $J$ & I & $\mathrm{N}$ & $\mathrm{B}$ & C. & I & G & B & $\mathbf{F}$ & D & $\mathrm{K}$ & F & 6 & 1 \\
\hline C. perezi & $\mathrm{E}$ & $\mathrm{H}$ & $\mathbf{F}$ & $\mathrm{J}$ & $\mathrm{K}$ & $\mathrm{N}$ & $\mathrm{B}$ & B & C: & $J$ & B & $\mathrm{F}$ & D) & $\mathrm{K}$ & $\mathrm{F}$ & c: & 1 \\
\hline C. plumbers & $\mathrm{E}$ & I & $\mathbf{M}$ & $\mathrm{F}$ & $\mathbf{K}$ & $N$ & $G$ & C & I & G & B & $\mathrm{F}$ & $J$ & C: & $\mathrm{F}$ & $C:$ & $A$ \\
\hline C. porosus & $\mathrm{E}$ & B & $\mathrm{N}$ & $\mathrm{F}$ & $F$ & D & M & $\mathrm{C}$ & I & (; & B & D & D & (3) & $\mathrm{F}$ & c : & $A$ \\
\hline G. sealer & B & C & 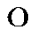 & $F$ & F & $\mathrm{K}$ & $\mathrm{E}$ & C. & I & C & B & D & D) & $\mathbf{P}$ & $\mathrm{F}$ & I & 1 \\
\hline C. sorrah & $\mathrm{E}$ & $\mathrm{H}$ & M & $\mathrm{F}$ & $\mathbf{K}$ & $\mathrm{E}$ & 1 & C & I & $B$ & B & $\mathrm{D}$ & I) & $\mathbf{Q}$ & $\mathrm{F}$ & $r$ & 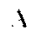 \\
\hline C. wheeleri & $\mathrm{E}$ & C: & $\mathrm{J}$ & $\mathrm{K}$ & D & $N$ & $B$ & C: & I & G & B & 1) & D) & $\tilde{D}$ & $F$ & C: & 1 \\
\hline G. cuvieri & $\mathrm{F}$ & $?$ & $\mathrm{~A}$ & I & $\mathrm{H}$ & B & 1 & C: & $\mathrm{E}$ & $\mathrm{A}$ & $\mathrm{D}$ & G & $\mathbf{K}$ & l: & D) & 1 & $A$ \\
\hline H. marrostoma & $\mathrm{H}$ & M & B & $F$ & A & $\mathrm{F}$ & $B$ & $\mathrm{~A}$ & $\mathrm{E}$ & D & $C$ & A & $\mathbf{H}$ & $V^{\prime}$ & (i & 1 & 1 \\
\hline H. mirrostoma & $\mathrm{H}$ & $\mathrm{N}$ & B & $\mathbf{F}$ & C: & $\mathrm{H}$ & $A$ & $A$ & $\mathrm{E}$ & D & I & A & $\mathbf{H}$ & $V^{\prime}$ & C: & i & $A$ \\
\hline 1. macrorhinus & $\mathrm{F}$ & $\mathrm{E}$ & $\mathrm{L}$ & $\mathbf{F}$ & B & C; & L. & C. & C: & C & $A$ & $\mathrm{H}$ & C: & $\mathrm{x}$ & C: & $\mathrm{F}$ & $d$ \\
\hline N. brevirostris & $\mathrm{F}$ & $\mathrm{E}$ & $\mathbf{R}$ & $\mathbf{K}$ & M & I & C: & ( & I & (i & B & $\vdots$ & $\mathbf{F}$ & $W$ & $\vdots$ & C & A \\
\hline P. glauca & $\mathrm{E}$ & I. & $\mathbf{M}$ & K & $J$ & 1. & $\mathrm{~F}$ & 1 & I & I & $B$ & $\mathrm{~F}$ & $\mathrm{~A}$ & $\mathrm{H}$ & $\mathrm{E}$ & f: & $A$ \\
\hline R. acutus & $\mathrm{F}$ & $\mathrm{D}$ & C & $\mathrm{H}$ & G & 0 & B & $\mathrm{F}$ & D & D) & $\mathrm{E}$ & $\mathrm{E}$ & B & $\mathrm{Y}$ & (: & 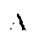 & $A$ \\
\hline R. lalandii & $\mathrm{A}$ & $\mathrm{D}$ & C & $\mathrm{H}$ & G & $\mathrm{P}$ & B & $\mathrm{F}$ & $\mathrm{D}$ & D & $\mathrm{E}$ & $\mathrm{E}$ & B & 1 & (i: & A & i \\
\hline R. porosus & $\mathrm{A}$ & $\mathrm{D}$ & $\mathrm{C}$ & $\mathrm{H}$ & G & $p$ & B & $\mathrm{F}$ & $\mathrm{D}$ & ( : & $\mathrm{F}$ & $\mathrm{E}$ & $\mathrm{B}$ & $\%$ & (i) & $i$ & 1 \\
\hline R. terranowae & $\mathrm{A}$ & D & C & $\mathrm{H}$ & G & $\mathrm{P}$ & $\mathrm{B}$ & $\mathrm{F}$ & $\mathrm{D}$ & C: & $\mathrm{E}$ & $\mathrm{E}$ & $\mathrm{B}$ & $\%$ & (: & $\therefore$ & 1 \\
\hline S. lewini & G & $\mathrm{H}$ & $G$ & $\mathrm{~B}$ & $\mathrm{H}$ & A & $\mathrm{N}$ & G & $\mathrm{B}$ & G & $\mathrm{H}$ & Ci & (;) & I. & $A$ & (: & 1 \\
\hline S. mockarran & G & $\mathrm{H}$ & $G$ & $\mathrm{D}$ & $\mathrm{H}$ & C; & $\mathrm{P}$ & G & $\mathrm{F}$ & F & $\mathrm{H}$ & $B$ & G & $\mathrm{F}$ & $B$ & C: & $A$ \\
\hline S. tiburo & G & $\mathrm{K}$ & G & C & $\mathrm{H}$ & $A$ & $x$ & $\mathrm{E}$ & $\mathrm{A}$ & G & $\mathrm{H}$ & C: & Gi & $\mathrm{M}$ & $A$ & $B$ & 4 \\
\hline S. tudes & G & k & G & C & $\mathrm{H}$ & $A$ & $X$ & $\mathrm{H}$ & B & $G$ & $\mathrm{H}$ & C: & $G$ & $M$ & $A$ & $B$ & 1 \\
\hline S. zygaena & G; & $\mathrm{H}$ & G & A & $\mathrm{H}$ & C: & $\mathrm{H}$ & G & $\mathrm{F}$ & D & $\mathrm{H}$ & $\mathrm{B}$ & $G$ & $\mathrm{R}$ & $A$ & i & 1 \\
\hline T. obesus & $\mathbf{F}$ & $\mathrm{E}$ & $\mathrm{E}$ & $\mathrm{F}$ & $\mathbf{E}$ & $\mathrm{M}$ & $\mathrm{E}$ & C & I & G & B & F & $\mathbf{F}$ & J & I & F & 1 \\
\hline
\end{tabular}

“(1) EST-1; (2) EST-2; (3) GOT-1; (4) GOT-2; (5) LDH-H; (6) ME-1; (7) ME-2; (8) SOD-1; (9) S()D-2; (10) $\alpha$ GPD; (11) MDH; (12) IDH; (13) CA; (14) PEP; (15) GDH; (16) GI O; (17) I AP. 
Appendix 2b. Character Matrix Numerically Coded with Autamorphic States Removed [Final, asymptotic character weights used for successive weighting (Farris, 1969) are given for each locus]

\begin{tabular}{|c|c|c|c|c|c|c|c|c|c|c|c|c|c|c|c|c|}
\hline Presumed locus ${ }^{a}$ & 1 & 2 & 3 & 4 & 5 & 6 & 7 & 8 & 9 & 10 & 11 & 12 & 13 & 14 & 15 & 16 \\
\hline C. acronotus & 2 & 5 & $?$ & 2 & 7 & 4 & $?$ & 2 & 5 & $?$ & 1 & 4 & 2 & 3 & 2 & 3 \\
\hline C. albimarginatus & 2 & 4 & 5 & 5 & 2 & 6 & 1 & $?$ & $?$ & $\mathbf{3}$ & 1 & 4 & 2 & $?$ & 3 & 3 \\
\hline C. altimus & 2 & 7 & 5 & 2 & 7 & 6 & 3 & 2 & 5 & $?$ & 1 & 6 & 5 & $?$ & 3 & 3 \\
\hline C. amblyrhynchos & 2 & 1 & 4 & 5 & 1 & 6 & 1 & 2 & 5 & 3 & $?$ & 4 & 2 & 2 & 3 & 3 \\
\hline C. brachyurus & 2 & 4 & $?$ & 2 & 7 & $?$ & 3 & 2 & 5 & 3 & 1 & 4 & 2 & $?$ & $?$ & $?$ \\
\hline C. brevipinna & 2 & 4 & $?$ & 2 & 7 & 3 & 3 & 2 & 5 & 3 & 1 & 4 & 2 & $?$ & 3 & 3 \\
\hline C. fulciformis & 2 & 3 & 5 & 4 & 6 & 3 & $?$ & 2 & 5 & 2 & 1 & 6 & 2 & 1 & $?$ & $?$ \\
\hline C. galapagensis & 2 & 9 & 5 & 4 & 6 & 6 & 1 & 2 & 5 & 3 & 1 & 6 & 2 & 4 & 3 & 3 \\
\hline C. isodon & 2 & 5 & 5 & $?$ & 7 & 5 & 2 & 2 & 5 & 3 & 1 & 4 & 2 & $?$ & 2 & $?$ \\
\hline C. leucas & $?$ & 6 & 5 & 2 & 7 & 6 & 2 & 2 & 5 & 3 & 1 & 4 & 2 & 6 & $?$ & 3 \\
\hline C. limbatus & 2 & 6 & $?$ & 2 & 3 & $?$ & 2 & 3 & $?$ & 3 & 1 & 4 & 2 & 6 & 3 & 3 \\
\hline C. longimanus & 2 & $?$ & 5 & 4 & 6 & 6 & 1 & 2 & 5 & 3 & 1 & 6 & 2 & 4 & 3 & 3 \\
\hline C. macloti & $?$ & $?$ & $?$ & $?$ & $?$ & 6 & 1 & 2 & 5 & $?$ & 1 & 4 & 2 & $?$ & 3 & $?$ \\
\hline C. melanopterus & 2 & 6 & $?$ & 5 & 7 & 6 & $?$ & 2 & 5 & 3 & 1 & 4 & $?$ & $?$ & 3 & 5 \\
\hline C. obscurus & 2 & 9 & 5 & 4 & 6 & 6 & 1 & 2 & 5 & 3 & 1 & 6 & 2 & 4 & 3 & 3 \\
\hline C. perezi & 2 & 6 & $?$ & 4 & 7 & 6 & 1 & $?$ & $?$ & $?$ & 1 & 6 & 2 & 4 & 3 & 3 \\
\hline C. plumbeus & 2 & 7 & 5 & 2 & 7 & 6 & 3 & 2 & 5 & 3 & 1 & 6 & 5 & 1 & 3 & 3 \\
\hline C. porosus & 2 & $?$ & $?$ & 2 & 3 & $?$ & $?$ & 2 & 5 & 3 & 1 & 4 & 2 & 3 & 3 & 3 \\
\hline C. sealei & $?$ & 1 & $?$ & 2 & 3 & 5 & 2 & 2 & 5 & 3 & 1 & 4 & 2 & $?$ & 3 & 5 \\
\hline C. sorrah & 2 & 6 & 5 & 2 & 7 & 3 & $?$ & 2 & 5 & $?$ & 1 & 4 & 2 & $?$ & 3 & 3 \\
\hline C. wheeleri & 2 & 1 & 4 & 5 & 1 & 6 & 1 & 2 & 5 & 3 & 1 & 4 & 2 & 2 & 3 & 3 \\
\hline G. cuvieri & 3 & $?$ & $?$ & $?$ & 5 & $?$ & $?$ & 2 & 3 & $?$ & $?$ & $?$ & $?$ & $?$ & $?$ & 1 \\
\hline H. macrostoma & 5 & $?$ & 1 & 2 & $?$ & $?$ & 1 & 1 & 3 & 2 & $?$ & 1 & 4 & 7 & 2 & 6 \\
\hline H. microstoma & 5 & $?$ & 1 & 2 & $?$ & $?$ & $?$ & 1 & 3 & 2 & $?$ & 1 & 4 & 7 & 2 & 6 \\
\hline L. macrorhinus & 3 & 3 & $?$ & 2 & $?$ & $?$ & $?$ & 2 & $?$ & 3 & $?$ & $?$ & $?$ & $?$ & 2 & 4 \\
\hline N. brevirostris & 3 & 3 & $?$ & 5 & $?$ & 4 & $?$ & 2 & 5 & 3 & 1 & $?$ & $?$ & $?$ & $?$ & 3 \\
\hline$P$. glauca & 2 & 9 & 5 & 5 & $?$ & $?$ & $?$ & $?$ & 5 & $?$ & 1 & 6 & $?$ & $?$ & $?$ & 3 \\
\hline R. acutus & 3 & 2 & 2 & 3 & 4 & $?$ & 1 & 3 & 2 & 2 & 2 & 5 & 1 & $?$ & 2 & 1 \\
\hline R. lalandii & 1 & 2 & 2 & 3 & 4 & 7 & 1 & 3 & 2 & 2 & 2 & 5 & 1 & $?$ & 2 & 1 \\
\hline R. porasus & 1 & 2 & 2 & 3 & 4 & 7 & 1 & 3 & 2 & 1 & $?$ & 5 & 1 & 8 & 2 & 1 \\
\hline$R$. terranovae & 1 & 2 & 2 & 3 & 4 & 7 & 1 & 3 & 2 & 1 & 2 & 5 & 1 & 8 & 2 & 1 \\
\hline S. lewini & 4 & 6 & 3 & $?$ & 5 & 1 & 4 & 4 & 1 & 3 & 3 & 3 & 3 & $?$ & 1 & 3 \\
\hline S. mockarran & 4 & 6 & 3 & $?$ & 5 & 2 & $?$ & 4 & 4 & $?$ & 3 & 2 & 3 & $?$ & $?$ & 3 \\
\hline S. tiburo & 4 & 8 & 3 & 1 & 5 & 1 & 4 & $?$ & $?$ & 3 & 3 & 3 & 3 & 5 & 1 & 2 \\
\hline S. tudes & 4 & 8 & 3 & 1 & 5 & 1 & 4 & $?$ & 1 & 3 & 3 & 3 & 3 & 5 & 1 & 2 \\
\hline S. zygaena & 4 & 6 & 3 & $?$ & 5 & 2 & $?$ & 4 & 4 & 2 & 3 & 2 & 3 & $?$ & 1 & 3 \\
\hline T. obesus & 3 & 3 & $?$ & 2 & 2 & $?$ & 2 & 2 & 5 & 3 & 1 & 6 & $?$ & $?$ & $?$ & 4 \\
\hline
\end{tabular}

${ }^{a}$ (1) EST-1, wt = 1000; (2) EST-2, wt = 489; (3) GOT-1, wt = 1000; (4) GOT-2, wt = 564; (5) L.DH-H, $\mathrm{wt}=533 ;(6) \mathrm{ME}-1, \mathrm{wt}=762 ;(7) \mathrm{ME}-2, \mathrm{wt}=467 ;(8)$ SOD-1, wt $=643 ;(9)$ SOD-2, wt $=1000 ;(10) \alpha \mathrm{GPD}$, $\mathrm{wt}=333$; (11) $\mathrm{MDH}, \mathrm{wt}=1000 ;(12) \mathrm{IDH}, \mathrm{wt}=778 ;(13) \mathrm{CA}, \mathrm{wt}=1000 ;$ (14) PEP, wt $=1000 ;(15) \mathrm{GDH}$, $\mathrm{wt}=1000 ;(16) \mathrm{GLO}, \mathrm{wt}=729$. 